\title{
The Effect of Customer Value on Behavioral Intentions in Tourism Industry
}

\author{
Wahyuningsih \\ Universitas Tadulako, Palu
}

\begin{tabular}{|c|c|}
\hline ARTICLE INFO & A B S T R A C T \\
\hline $\begin{array}{l}\text { Received: August 24, } 2011 \\
\text { Final revision: February } 12,2012\end{array}$ & $\begin{array}{l}\text { Customervalue is a recent line of research that is attracting the attention } \\
\text { of the marketers. The objective of this study is to investigate tourists' }\end{array}$ \\
\hline $\begin{array}{l}\text { Keywords: } \\
\text { customer value, } \\
\text { behavioral intentions, } \\
\text { tourism. }\end{array}$ & $\begin{array}{l}\text { perceived value and its effect on future behavioral intentions of tourists } \\
\text { to revisit. Data have been collected through questionnaires which } \\
\text { were supported by in-depth interviews with tourists visiting Togean } \\
\text { Islands, one of the most popular tourism destinations in Indonesia. The } \\
\text { proposed research model of has been tested using Stuctural Equation } \\
\text { Modeling. Results of this study that tourists who perceive higher levels } \\
\text { of value will have stronger intentions to revisit the tourism destination } \\
\text { and will recommend it to other people. Three main aspects which } \\
\text { are needed to be improved to increase the number of tourists to visit } \\
\text { Togean Islands are communications, transportations, and cleanliness. } \\
\text { This study also provides managerial implications, conclusion, and } \\
\text { future research directions. }\end{array}$ \\
\hline
\end{tabular}

(c) 2012 IRJBS, All rights reserved.

$\mathrm{T}$ ourism has been seen as the driving force for regional development (Chen and Tsai, 2007). In an increasingly competitive international tourism market with emerging new destinations, mature tourist destinations can gain a competitive edge through repeat visitation (Alegre and Cladera, 2009). Tourism which is managed professionally might increase society income, reduce unemployment, and increase government's revenues. How to attract tourists to visit, revisit and recommend the destination to other people is crucial for the success of destination tourism development.

Recentyears, perceivedvaluehasbeenemphasized as the object of attention by researchers in tourism (Meng, Liang and Yang, 2011; Pechlaner, Smeral and Matzier, 2002; Oh et. al, 2004; Petrick, 2004; Petrick, Morais, and Norman, 2001; Sanchez et. al, 2006). The creation and transmission of value to tourists has become a competitive advantage of 
the first order, in environments characterized by globalized competition and by tourists who are more and more demanding (Flagestad and Hope, 2001)

Furthermore, empirical research also reveals that there is positive impact of perceived value on both future behavioral intentions and behaviors (Bolton and Drew, 1991; Chang and Wildt, 1994; Grisaffe and Kumar, 1998). Hence, perceived value has been shown to be good predictors of future behavioral intentions.

\section{Customer Value}

Marketing involves exchanges; exchanges depend on customer value, therefore, customer value plays a crucial role at the heart of marketing activity (Holbrook, 1999). This is inline with Gale's argument that value has been considered as an essential element of an organization's competitive strategy (Gale, 1994). Organization who have a strong focus upon customer value will form a sustainable competitive advantage (Woodruff, 1997). The rationale behind this is that, delivering better value to customers might result in a likelihood of purchase, repeat purchase, and positive word-of-mouth communication (Bolton and Drew, 1991; Grisaffe and Kumar, 1998; Sweeney, Soutar and Mazzarol, 2011). In other words, if the organizations know what drives value for its customers and provides superio customer value, they have a greater probability of obtaining and retaining customers (Gabbott, 2004). Therefore, it can be noticed that in-depth understanding of customer value is very importan for companies to succeed.

In this study, customer value is defined as "a difference between total benefits and tota sacrifices perceived by consumers in purchasing a product or service". Total benefits are a combination of physical attributes, service attributes, and technical support available in relation to a particular use situation (Monroe, 1990). Meanwhile, sacrifices are what the consumers have to give up in obtaining the purchased products. These are defined from the customer's perspective (Monroe, 1990) and include monetary terms (Anderson, Jain, and Chintagunta, 1993) and non-monetary terms such as energy, time and effort (Cronin et al., 1997). Within the identification of benefits and sacrifices, consumers not only consider the performance or functional matters but also social and emotional factors (Sheth et. al, 1991; Sheth et. al, 1999; Sweeney and Soutar, 2001). Therefore, the investigation of customer value covers functional value, social value, and emotional value

Functional value is defined as the perceived utility acquired from an alternative's capacity for functional, utilitarian, or physical performance (Sheth et. al, 1991). In other words, it is the quality of physical outcome of using the product or service, which refers to how well a product or service serves its principal physical function consistently (Sheth et. al, 1999). Functional value is related to economic utility, the benefits associated with possessing the product or service, and underlies the performance of the object on a series of salient attributes such as price, reliability, and durability.

Social value is the perceived utility acquired through the consumption of an alternative as a result of its association with one or more specific social groups (Sheth et. al., 1991). Alternatives acquire social value through association with positively or negatively stereotyped demographic, socioeconomic, and cultural-ethnic groups (Sheth et al.,1991). In other words, social value is the utility derived from the product's ability to enhance social self-concept (Sweeney and Soutar, 2001; Wang et al., 2004). Consumers choose the products that convey an image congruent with the norms of their friends and associates, or that convey the social image they wish to project (Sheth et al., 1999).

Emotional value is the economic value or monetary worth of feelings when customers experience an organisation's products and/or services (Barlow and Maul, 2000). It further refers to the feelings that customers experience or anticipates experiencing when they deal with organisations and their representatives (Barlow and Maul, 2000). Likewise, Sheth et al. (1991) in agreement with Wang et al. (2004) define emotional value as the perceived utility acquired by consuming an alternative as a result of its ability to arouse feelings or affective states. They maintain that many products are associated with or facilitate the arousal of specific emotions or feelings; for example, comfort, security, excitement, romance, passion, anger, fear, and guilt. Therefore, to analyze how customers value a product, it is important to take these emotions into account.

\section{Behavioral Intentions}

Two behavioral intentions investigated in this study include repurchase intentions and word-of-mouth communication. The discussion concerning the two concepts is presented as follows:

\section{Repurchase Intentions}

Since behavioral intentions are easier to measure than actual behavior, there are numerous studies of repurchase intentions (Bolton, Kannan, Bramlett, 2000). However, these studies must be interpreted with caution because behavioral intentions are subject to criticism since intentions do not always lead to actual behavior (e.g. Gabler and Jones, 2000; Morwitz and Schmittlein, 1992).

Repurchase intentions are defined as "the individual's judgment about buying again a designated service from the same company, taking into account his or her current situation and likely circumstances" (Hellier, 2003, p.1764). From this definition, it is clear that repurchase behavior occurs when customers purchase other products or services for the second or more times with the same company; and the reason for purchasing again is mainly triggered by customer experience towards the products or services.
Theory suggests that increasing customer retention is a key act of the ability of a company to generate profits (Zeithaml, Berry, Parasuraman, 1996). This is because the longer consumers stay with a company, the more products or services they buy from the company and no excess marketing outlay to win new customers. To retain customers, a company needs to improve its service quality, which in turn leads to high service value (Cronin Brady, Hult, 2000). Thus, it is noticed that consumers are more likely to purchase again from the same company if they think that what they have received was worth what they have given up.

\section{Factors Influencing Consumer's Repurchase}

\section{Intentions}

Hellier et al. (2003) argue that customer repurchase intentions are influenced by seven importan factors. Namely, service quality, equity, value, customer satisfaction, past loyalty, expected switching cost, and brand preference. The study by Petrick, Morais, and Norman (2001) suggests that consumers' intention to repurchase is influenced by three factors: past behavior, satisfaction, and perceived value. More specifically, Jones and Suh (2000) state the repurchase intention is determined by overall satisfaction. They suggest that when overall satisfaction is high, transaction-specific satisfaction (the consumer's dis/satisfaction with discrete service encounter) has little impact on repurchase intentions, but when overall satisfaction is low, transaction-specific satisfaction has a positive influence on repurchase intentions. This is supported by Diaz and Ruiz (2002) who assert tha customer satisfaction is a primary precursor of repeat purchase behavior. From these arguments, it can be noticed that customer value has a positive influence on repurchase intentions

\section{Word-of-Mouth Communication (WoM)}

WoM communication is defined as "informal communications directed at other consumers about the ownership, usage, or characteristics of particular goods and services and/or their sellers" (Westbrook, 1987, p.261). The more 
general definition of WoM as giving or receiving comments about product or service (Sweeney et. al., 2011). The reasons for customers doing WoM communications are because they want to ease a tension that the positive or negative experience produced, to reassure themselves in front of others, to gain support from others who share their opinions, to gain attention or to share the benefits of things enjoyed (Wirtz and Chew, 2002).

WoM has been identified in previous research as an important behavior after consuming a product or service (e.g. Gremler, Gwinner, and Brown, 2001; Wirtz and Chew, 2002). This is primarily because WoM communication provides face-to-face, often vivid information that is highly credible (Spreng et. al, 1995). In addition, consumers frequently rely on informal and/or personal communications sources in making purchase decisions as opposed to more formal and/or organizational sources such as advertising campaigns (Bansal and Voyer, 2000). Furthermore, WoM has been widely acknowledged as an informal communication source between consumers that has grea economic impact (Murray, 1991). Customers who show up on the strength of a persona recommendation tend to be more profitable and stay with the company longer than customers who respond to conquest advertising, sales pitches, or price promotions (Reichheld, 1996). From the previous studies, it is perceived that WoM plays a key role in shaping consumers attitudes and behaviors (Harrison-Walker, 2001). Thus, WoM serves as enforcement to consumers to remain loyal to a service provider.

WoM is more important and influential within service context than strictly just product marketing scenarios, given their intangibility and highe associated risk. Compared to purchasers of goods, Murray (1991) found that service buyers have greater confidence in personal sources of information as well as a greater pre-purchase preference for personal information sources. In addition, Ennew et al. (2000) suggest that WoM may also be one of the most powerful form of communication within financial services, given they tend to be characterized by a predominance of experience and credence qualities. A consumer may not understand a service fully before its consumption; he or she might seek WoM information from an experienced source (Bansal and Voyer, 2000). Therefore, WoM becomes especially important within the services purchase decision context.

\section{The Relationship between Customer Value and}

\section{Behavioral Intentions}

Most conceptual and empirical contributions to value literature conceive a direct impact of customer value on behavioral outcomes neglecting the role of satisfaction (Eggert and Ulaga, 2002). For example, Grisaffe and Kumar (1998) point out two behavioral intentions as direct consequences of customer value. These are customer likelihood to recommend and likelihood to continue doing business with the company. This is in agreement with the Petrick's (2002) argument that customer value has a direct impact on repurchase intentions and word-of-mouth communication. In addition, Bolton and Drew (1991) found that value is related to customers' subscription intentions and intentions to recommend, This is in line with the study by Hartline and Jones (1996) who suggest that value leads to the increase of wordof-mouth intentions. Moreover, Chang and Wildt (1994) found that perceived value mediates the relationship between perceived quality, perceived price, and purchase intention. The model of these relationships can be seen in Figure 1

Further to the above discussion, Cronin et al. (1997) propose the value added model which examines service quality and sacrifice as a direct measure of value that has a direct link to purchase intentions. They found that the addition of a direct measure of service value to the model which is defined solely by service quality and sacrifice increases the ability of the model to explain variance in consumers' purchase intentions.

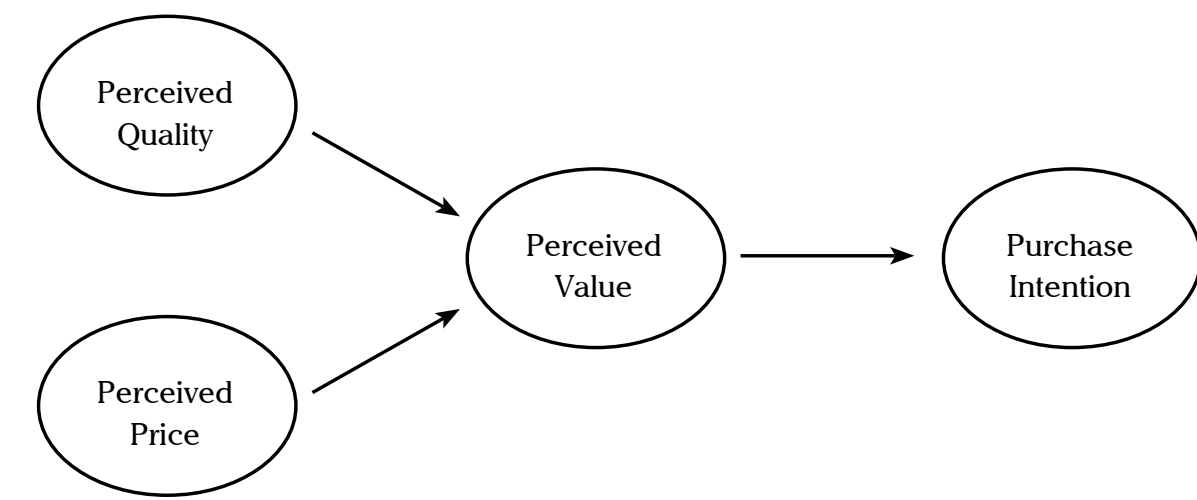

Figure 1. A Direct Link between Value and Purchase Intentions (Adapted from Chang and Wildt (1994))

Basically, a rationale for neglecting satisfaction is provided by Gross (1997) who argues that in business markets, purchasing managers' decision making is mainly guided by cognitive factors and not by affective ones. Therefore, a direct link between value and outcome variables has been developed taking into consideration solely the cognitive input and cognitive output which consist of repurchase intentions, search for alternatives, and word-ofmouth communication (Eggert and Ulaga, 2002). In consumer markets, buying decision-making is determined by both cognitive and affective factors (Sheth et al., 1991). Hence, it is reasonable to argue that there is a direct relationship between value and behavioral intentions in consumer markets since value involves emotional aspects which, according to most of the literature, can only be captured in the study of customer satisfaction. In this context, customer value is supposed to have a direct impact on behavioral intentions.

Grewal, Monroe, and Krishnan (1998) and Sweneey, Soutar, and Johnson (1999) suggest that in a pre-purchase situation, perception of value might directly influence willingness to buy. Chen and $\mathrm{Hu}(2010)$ argue that perceived value drives customer loyalty. This is because the most satisfied customer may not necessarily be the most loyal; thus, value is a better predictor for loyalty. The key foundation underlying all these studies is that value is the key linkage between the cognitive elements of perceived quality or performance, perceived sacrifice, and behavioral intentions (Patterson and Spreng, 1997). Based on these previous studies, it is noticed that value may well directly impact on behavioral intentions. Based on this discussion, it is hypothesized that "customer value has a positive impact on behavioral intentions".

\section{METHODS}

This study investigates the impact of value perceived by tourists on their behavioral intentions to revisit. In other words, what are the tourist going to do in the future after they perceive high or low level of value. The unit of analysis of this study is individuals, specifically, tourists who visit Togean Islands in Central Sulawesi, Indonesia. To collect data, closed-ended questions in a structured questionnaire were used to capture the perceived value. To complete the information from collected questionnaires, in-depth interviews with selected tourist have been conducted.

A convenience sample of 200 questionnaires was distributed directly to respondents. Out of 200 questionnaires, 135 questionnaires were received and completed. Thus, the response rate in this survey was $68 \%$.

The data analysis technique used in this study is Structural Equation Modeling (SEM). SEM was employed to build and test the measurement 
model, which enables a comprehensive, confirmatory assessment of construct validity, and provides a confirmatory assessment of convergen validity and discriminant validity (Anderson and Gerbing, 1988), as well as to test the conceptual study of relationship between customer value and behavioral intentions.

\section{RESULTS AND DISCUSSION}

Results from testing the model using structural equation modeling indicates that there is positive significant relationship between customer value and behavioral intentions as shown in Figure 2 and Table 1.

The result shows that the model $\mathrm{X}^{2}$ is 4.960 with degree of freedom 3. Thus the likelihood-ratio chisquare $\left(\mathrm{X}^{2} / \mathrm{df}\right)$ is $1.653 . \mathrm{X}^{2} / \mathrm{df}$ ratios of less than 3 have been interpreted as indicating a good fit to the data. Hence, the $\mathrm{X}^{2} / \mathrm{df}$ ratio of 1.653 from the model indicates a good fit.

The Goodness-of-Fit Index (GFI) is a measure of the relative amount of variance and covariance between variables that are predicted by sample size (Bollen, 1989). The AGFI differs from the GF only in the fact that it adjusts for the number o degrees of freedom in the specified model (Byrne, 1998). Although both indexes range from zero to

1.00 , with values close to 1.00 being indicative of good fit, and 1.00 indicating a perfect fit (Arbuckle, 1999). Based on the GFI and AGFI reported in Table 1 (.981 and .937, respectively), it confirms that the hypothesised model fits the sample data fairly well.

Root Mean-Square Error of Approximation (RMSEA) takes into account the error of approximation in the population and asks the question, "How well would the model, with unknown but optimally chosen parameter values, fit the population covariance matrix if it were available (Byrne, 1998, p.84). A value about 0.08 or less for the RMSEA would indicate a reasonable error of approximation (Browne and Cudeck, 1993). Thus, a value of .070 for the RMSEA shows that the model performs well.

Based on the result of Structural Equation Modeling, this study found that the higher the level of perceived value, the stronger their intentions to revisit Togean Islands as well as their willingness to recommend to others. The perceived value is dependent upon the perceived benefits and sacrifices. As mentioned before, benefits are a combination of physical available in relation to a particular use situation

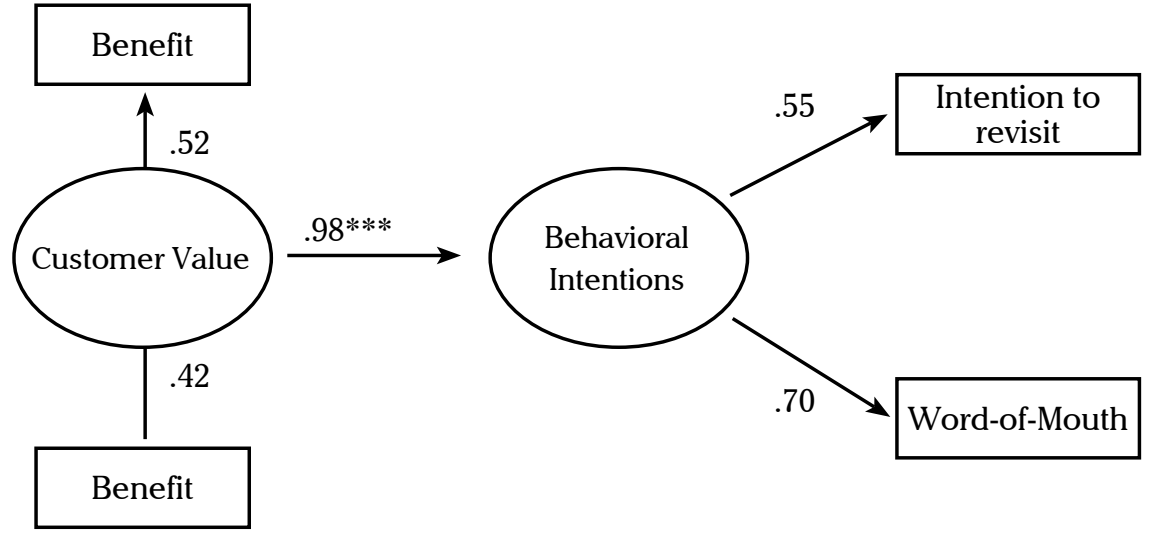

Figure 2. The Relationship between Customer Value and Behavioral Intentions

\section{Table 1. Summary of Model Fit}

\begin{tabular}{lc}
\hline Model Fit Assessment & Result \\
\hline $\mathrm{X}^{2}$ & 4.960 \\
Degree of freedom & 3 \\
P-value & .175 \\
$\mathrm{X}^{2} /$ /df & 1.653 \\
GFI & .981 \\
AGFI & .937 \\
NFI & .923 \\
TLI & .933 \\
RMSEA & .070 \\
\hline
\end{tabular}

(Monroe, 1990). Meanwhile, sacrifices are what the consumers have to give up in obtaining the purchased products. Hence, this study agrees with previous studies (Bolton and Drew, 1991; Chang and Wildt, 1994; Grisaffe and Kumar, 1998; Hartline and Jones, 1996; Chen and Hu, 2010; Meng et. al, 2011) which argue that customer value has a direct impact on repurchase intentions and wordof-mouth communication. Specifically, this result is in agreement with Petrick's study (2004) who points out those customers who perceive high levels of value, they have high level of intentions to revisit the tourism destination.

The perceived value is the trade-off relationship between perceived benefits on the other hand and monetary and non-monetary sacrifices on the other, with highly personalized involvement and abstract level activities (Meng, et. al, 2011). As applied to tourim industry, evaluating perceive value is not limited to the monetary aspects, and it might be more important to take the non-monetary aspects. In this regard, this study presents the levels of value perceived by tourists. The result is depicted in Figure 3.

The figure 3indicates that most of tourists who were visiting Togean Islands perceived fair value $(57 \%)$, while others perceived high levels and very high levels of value, $28 \%$ and $11 \%$ respectively. Fair value means that these tourists perceived benefits equal to the sacrifices (monetary and nonmonetary i.e. price, time, and effort) that they gave up. High value and very high value means that the compared to the sacrifices that they had to give up.

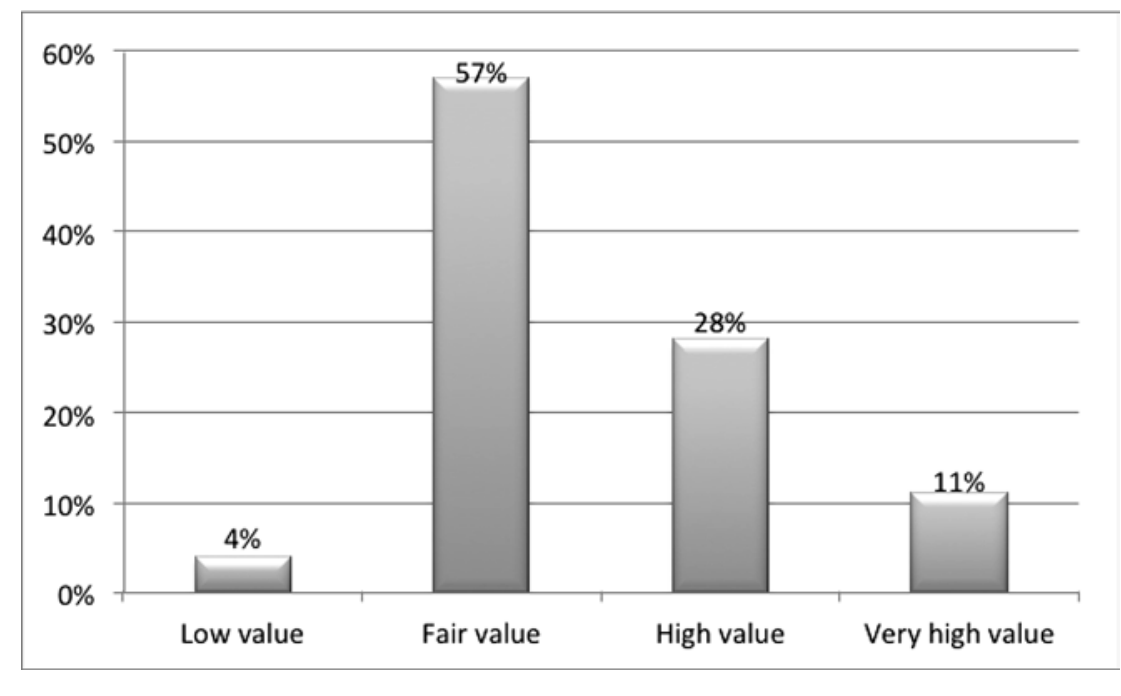

Figure 3. Levels of Value Perceived by Tourists 
Three indicators of benefits which were perceived very good by tourists are society acceptance (MEAN 4.19), enjoyment (MEAN 4.18), and view (MEAN 4.03). Society acceptance, as one item of social value, is the way of community who live in tourism area to welcome these visitors. Enjoyment, as one item of emotional value, means that tourists feel very enjoy when they are visiting Togean Islands. View, as one item of functional value, is great and beautiful view and scenery in Togean Islands.

\section{MANAGERIAL IMPLICATIONS}

This study found $4 \%$ of tourists who perceived low levels of value. Hence, service providers who play role in supplying tourism products, need to increase the level of perceived value by providing better benefits for tourists. This is crucial as it has been confirmed by the results of this study that the levels of perceived value will have a positive significant effect on tourists' future behaviora intentions in terms of repurchase intentions (revisit) and recommend to other people (positive word-of-mouth communication)

This study found three main indicators of functional value which need to be improved i.e. communication facilities, cleanliness, and transportation. The results can be seen in Table 2 .

This is in line with the opinion of tourists from in depth-interviews stating that they hardly found communication devices such as internet and telephone, un-scheduled transportation, and un-clean environments (rubbish everywhere)

\begin{tabular}{clc} 
Table 2 MEAN of Indicators & \\
\hline Rank & \multicolumn{1}{c}{ Indicators } & $\begin{array}{c}\text { MEAN } \\
\text { scale 1-5 } \\
\text { (Very bad to Very Good) }\end{array}$ \\
\hline $1^{\text {th }}$ & Society acceptance & 4.19 \\
$2^{\text {nd }}$ & Enjoyment & 4.18 \\
$3^{\text {rd }}$ & View & 4.03 \\
$4^{\text {th }}$ & Food and beverages & 3.89 \\
$5^{\text {th }}$ & Security & 3.79 \\
$6^{\text {th }}$ & Accommodations & 3.59 \\
$7^{\text {th }}$ & Cleanliness & 2.81 \\
$8^{\text {th }}$ & Transportation & 2.63 \\
$9^{\text {th }}$ & Communication & 2.14 \\
\hline
\end{tabular}
attention to" people.
Based on these results, this study suggests that to

Waste disposal; a serious problem that must be tacked immediately \& urgently - maybe partly with composting \& recycling as much possible use less plastic etc. if Togean want to be a proper tourist destination. It could be end before it starts if the environmental issues are not given great

“...no place to get an access to the internet...not all cards for cell-phone can be used..."

It is clear that tourism service providers including regional government need to pay greater attentions on communication and cleanliness of the environment in Togean Islands, transportation to Togean Islands and within Togean Islands. If these three aspects can be improved, it will increase the levels of value perceived by tourists who lead to their intention to revisit and recommend to other

\section{REFERENCES} Return", European Journal of Marketing, 40 (5/6), 670-685 to-Business Marketing, 1, 3-29. Service Research, 3 (2), 166-177. Consumer Research, 17 (4), 375-384. Research, 19 (1), 579-583. increase level of value perceived by tourists, service providers should improve all the dimensions of value i.e. functional value, social value, and emotional value. Functional value can be improved by providing better accommodation, cleanliness, transportation and facilities. Social value can be improved by providing society acceptance (friendliness) and better service quality. In addition, emotional value can be improved by increasing the level of enjoyment and security perceived by tourists. Therefore, tourists will perceive high value (functional, sosial and emotional value), likely to revisit and recommend to other people.

of co-operation (Pechlaner et. al, 2002). Options to improve a destination's competitive edge depend on the determinants of perceived value. It has been indicated in the results of this study that three main areas need to be improved i.e. communication, transportation, and cleanliness in order to increase customer perceived value which might lead to intentions to revisit the destination. More precisely, service providers including regional government and private businesses need to provide communication facilities (mobile phone providers, access to the internet), easy, convenient, and clear timetable of transportation, as well as increase the awareness of community to maintain the cleanliness of the area.

\section{CONCLUSION}

The empirical result of this study confirms the previous studies which agree that there is positive significant impact of perceived value on behavioral intentions. Hence, this study points out that the higher the customer perceived value, the stronger their future behavioral intentions to revisit and recommend to other people.

Destinations are strategic marketing units which consist of territorially delimited, consolidated areas

This study is subject to some limitations. First, thi investigation refers only to a specific geographica area i.e. Togean Islands, Central Sulawes Indonesia. Consequently, future research would be useful for generalizing the results to other geographical areas. Second, this research olny investigates two contructs, hence further research is suggested to include other constructs such as destination image and satisfaction to perform and test a comprehensive framework.

Alegre, Joaquin and M. Cladera (2009), "Analyzing the Effect of Satisfaction and Previous Visits on Tourists Intentions to

Anderson, J.C., C. Jain, and P.K. Chintagunta (1993), “Customer Value Assessment in Business Markets, Journal of Business ----, and D.W. Gerbing (1988), "Structural Equation Modeling in Practice: A Review and Recommended Two-Step Approach,"
Psychological Bulletin, 103 (3), 411-423.

Arbuckle, J.L. (1999), AMOS 4.0 User's Guide. Chicago, The USA: SmallWaters Co

Bansal, H.S. and P.A. Voyer (2000), "Word-of-Mouth Processes Within A Services Purchase Decision Context," Journal

Barlow, J. and D. Maul (2000), Emotional Value: Creating Strong Bonds with Your Customers. San Fransisco: Berrett-Koehler. Bollen, K.A. (1989), Structural Equations with Latent Variables. New York: John Wiley \& Sons.

Bolton, R.N. and J.H. Drew (1991), “A Multistage Model of Customers' Assessments of Service Quality and Value," Journal of

-, P.K. Kannan, and Matthew D. Bramlett (2000), "Implications of Loyalty Program Membership and Service Experiences for Customer Retention and Value," Journal of the Academy of Marketing Science, 28 (1), 95-108.

Bone, P.F. (1992), "Determinants of Word-of-Mouth Communication During Product Consumption," Advances in Consumer 

Browne, M.W. and R. Cudeck (1993), "Alternative Ways of Assessing Model Fit," in Testing Structural Equation Models,
Kenneth A. Bollen and J.S. Long, Eds. Newbury Park, CA: Sage.

Byrne, B.M. (1998), Structural Equation Modelling with LISREL, PRELIS, and SIMPLIS: Basic Concepts, Applications, and Programming. Mahwah, New Jersey: Lawrence Erlbaum Associates.

Chang, T-Z and A.R. Wildt (1994), "Price, Product Information, and Purchase Intention: An Empirical Study," Journal of the

Chen, C-F. and D. Tsai (2007), "How Destination Image and Evaluative Factors Affect Behavioral Intentions?," Tourism

Chen, Po-Tsang and H. H. Hu, (2010), "The Effect of Relational Benefits on Perceived Value in Relation to Customer Loyalty: An Empirical Study in the Australian Coffee Outlets Industry", International Journal of Hospitality Management", 29 (3),

Cronin, Joseph, M. Brady, R.Brand, R. Hightower, and D. Shemwell (1997), "A Cross-Sectional Test of the Effect and Conceptualization of Service Value," The Journal of Service Marketing, 11 (6), 357-39 .

- , M. Brady, and T.M. Hult (2000), "Assessing the Effects of Quality, Value, and Customer Satisfaction on Consumer Behavioral

Diaz, A.B.C. and F. Ruiz (2002), "The Consumer's Reaction to Delays in Service," International Journal of Service Industry Management, $13(2), 118-140$

Eggert, A. and W. Ulaga (2002), "Customer Perceived Value: A Substitute For Satisfaction in Business Markets?," Journal of Business \& Industrial Marketing, 17 (2/3), 107-118. Ennew, C., A. Banerjee, and D. Li (2000), "Managing Word of Mouth Communication: Empirical Evidence From India,"
International Journal of Bank Marketing, 18 (2), 75-83.

Flagestad, A. and C.A. Hope (2001), "Strategic Success in Winter Sports Destinations: A Sustainable Value Creation Perspective," Tourism Management, 22, 445-461.

Gabbott, M. (2004), Introduction to Marketing: a Value Exchange Approach. New South Wales, Australia: Prentice Hall.

Gabler, J. and M.Y. Jones (2000), "Behavior and Behavioral Intentions in a Retail Setting," ANZMAC 2000 Visionary Marketing for the 21st Century: Facing the Challenge, 377-382.

Gale, B.T. (1994), Managing Customer Value. New york, The USA: The Free Press.

Gonzalez, M.E.A., L.R. Comesana, and J.A.F. Brea (2007), "Assessing Tourist Behavioral Intentions through Perceived Service Quality and Customer Satisfaction," Journal of Business Research, 60, 153-160.

Gremler, D.D, K.P. Gwinner, and S.W. Brown (2001), "Generating Positive Word-of-Mouth Communication through CustomerEmployee Relationships," International Journal of Service Industry Management, 12 (1), 44-59.

Grewal, D., K.B. Monroe, and R. Krishnan (1998), "The Effects of Price-Comparison Advertising on Buyers' Perceptions of Acquisition Value, Transaction Value, and Behavioral Intentions," Journal of Marketing, 62 (April), 46-59,

Grisaffe, D.B. and A. Kumar (1998), "Antecedents and Consequences of Customer Value: Testing an Expanded Framework," Marketing Science Institute, 98-107, 1-32.
.

Gross, I (1997), "Evolution in Customer Value: the Gross Perspective," in Customer Value: Moving Forward - Back to Basics, B. Donath, Ed.: ISBM Report No.13.
B.

Harrison-Walker, L.J. (2001), "The Measurement of Word-of-Mouth Communication and an Investigation of Service Quality and Customer Commitment as Potential Antecedents," Journal of Service Research, 4 (1), 60-77

Hartline, M.D. and K.C. Jones (1996), "Employee Performance Cues in a Hotel Service Environment: Influence on Perceived Service Quality, Value, and Word-of-Mouth Intentions," Journal of Business Research, 35 (3), 207-215.

Hellier, P.K., G. Geursen, R.A. Carr, and J.A. Rickard (2003), "Customer Repurchase Intention: A General Structural Equation Model," European Journal of Marketing, 37 (11/12), 1762-1800.

Holbrook, M.B. (1999), Consumer Value: A Framework for Analysis and Research. New York: Routledge.

Jones, M.A. and J. Suh (2000), "Transaction-Specific Satisfaction And Overall Satisfaction: An Empirical Analysis," Journal of Service Marketing, 14 (2), 147-15. Kashyap, R. and D. Bojanic (2000), “A Structural Analysis of Value, Quality, and Price Perceptions of Business and Leisure
Travelers," Journal of Travel Research, 39 (August), 45-51.

Meng, Shiang-Min, G.S. Liang and S.H. Yang, (2011), "The Relationships of Cruise Image, Perceived Value, Satisfaction, and Post-Purchase Behavioral Intention on Taiwanese Tourists", African Journal of Business Management, 5 (1), 19-29.

Monroe, K.B. (1990), Pricing: Making Profitable Decisions. New York, The USA: McGraw-Hill.

Morwitz, V.G. and D. Schmitttlein (1992), "Using Segmentation to Improve Sales Forecast Based on Purchase Intention," Journal of Marketing Research, 29 (November), 391-406.

Murray, K.B. (1991), “A Test of Services Marketing Theory: Consumer Information Acquition Activities," Journal of Marketing, $55(1), 10-25$.
Neal, W.D. (1999), "Satisfaction is Nice, but Value Drives Loyalty," Marketing Research (Spring), 21-23.

Oh, H, Kim. B.Y. and J.H. Shin, (2004), "Hospitality and Tourism Marketing: A Recent Developments in Research and Future

Patterson, Paul G. and Richard A. Spreng (1997), Modelling The Relationship Between Perceived Value, Satisfaction and Repurchase Intentions in a Business-(10-Bust)

Pechlaner, Harald, E. Smeral and K. Matzier, (2002), "Customer Value Management as a Determinant of the Competitive , Therism Review, 57 (4), 15-22.

Petrick, J.F. (2004), "The Roles of Quality, Perceived Value and Satisfaction in Predicting Cruise Passengers' Behaviora Intentions," Journal of Travel Research, 42(4), 397-407.

-, D.D. Morais and W. Norman (2001), “An Examination of the Determinants of Entertainment Vacationers' Intentions to

Reichheld, F.(1996), The Loyalty Effect: The Hidden Force Behind Growth, Profits, and Lasting Value. Boston: Harvard Busines School Press.

Sanchez, J., L. Callarisa, R.M. Rodriguez, and M.A. Moliner (2006), "Perceived Value of the Purchase of a Tourism Product," Tourism Management, 27, 394-409,

Sheth, J.N, B. Mittal, and B. I. Newman (1999), Customer Behavior: Consumer Behavior and Beyond. The USA: The Dryden Press.

,--- , B.I. Newman, and B.L. Gross (1991), Consumption Values and Market Choice. Cincinati, Ohio: South Western Publishing Spreng, R.A., G. Harrell, and R.D. Mackoy (1995), "Service Recovery: Impact on Satisfaction and Intentions," Journal of Services Marketing, $9(1), 15-23$.

Sweeney, J.C. and G.N. Soutar (2001), "Consumer Perceived Value: The Development of a Multiple Item Scale," Journal or Retailing, 77 (2), 203-20.

---, G.N. Soutar, and L.W. Johnson (1999), "The Role of Perceived Risk in the Quality-Value Relationship: A Study in a Retail Environment," Journal of Retailing, 75 (1), 77-105.

---, G.N. Soutar and T. Mazzarol, (2011), "Word-of-Mouth: Measuring the Power of Individual Messages", European Journal of Marketing, 46, (1/2), 1-35

Wang, Y., H.P. Lo, R. Chi, and Y. Yang (2004), "An Integrated Framework for Customer Value and Customer-RelationshipManagement Performance: A Customer-Based Perspective from China," Managing Service Quality, 14 (2/3), 169-182.

Westbrook, R.A. (1987), "Product/Consumption-Based Affective Responses and Postpurchase Processes," Journal of Marketing Research, 24 (3), 258-270.

Wirtz, J. and P. Chew (2002), "The Effects of Incentives, Deal Proneness, Satisfaction and Tie Strength on Word-of-Mouth Behaviour," International Journal of Service Industry Management, 13 (2), 141-162.

Woodruff, R.B. (1997), "Customer Value: The Next Source for Competitive Advantage," Journal of the Academy of Marketing Science, 25 (2), 139-153.

Zeithaml, V.A. (1988), "Consumer Perceptions of Price, Quality, and Value: A Means-End Model and Syntesis of Evidence," Journal of Marketing, 52 (July), 2-22.

--.-, L. Berry, and A. Parasuraman (1996), "The Behavioral Consequences of Service Quality," Journal of Marketing, 60 (April) $31-46$ 
Appendix

Profile of Respondents

\begin{tabular}{|c|c|c|}
\hline Description & $\begin{array}{c}\text { Frequency } \\
(\mathrm{N}=135)\end{array}$ & Percentage \\
\hline $\begin{aligned} \text { Type of tourist } \\
-\quad \text { Domestics } \\
-\quad \text { Overseas }\end{aligned}$ & $\begin{array}{l}61 \\
74\end{array}$ & $\begin{array}{l}45.2 \% \\
54.8 \%\end{array}$ \\
\hline $\begin{array}{l}\text { Country of origin } \\
\begin{aligned} \text { - } & \text { Asia } \\
\text { - } & \text { America and Canada } \\
\text { - } & \text { European countries } \\
\text { - } & \text { Australia }\end{aligned}\end{array}$ & $\begin{array}{c}66 \\
8 \\
61 \\
0\end{array}$ & $\begin{array}{c}48.9 \% \\
54.8 \% \\
45.2 \% \\
0 \%\end{array}$ \\
\hline $\begin{array}{l}\text { Gender } \\
\begin{aligned} & \\
- & \text { Female } \\
- & \text { Male }\end{aligned}\end{array}$ & $\begin{array}{l}73 \\
62\end{array}$ & $\begin{array}{l}54.1 \% \\
45.9 \%\end{array}$ \\
\hline $\begin{array}{l}\text { Age } \\
\begin{aligned} \text { - } & \text { Less than } 19 \\
- & 20-29 \\
- & 30-39 \\
- & \text { More than } 40\end{aligned}\end{array}$ & $\begin{array}{c}4 \\
48 \\
42 \\
41\end{array}$ & $\begin{array}{c}3 \% \\
35.6 \% \\
31.1 \% \\
30.4 \%\end{array}$ \\
\hline $\begin{array}{l}\text { Occupation } \\
\begin{aligned} \text { - } & \text { Work for government } \\
\text { - } & \text { Businessman/Entrepreneur/Work for a company } \\
\text { - } & \text { Work for university } \\
\text { - } & \text { Others }\end{aligned}\end{array}$ & $\begin{array}{l}41 \\
44 \\
19 \\
31\end{array}$ & $\begin{array}{l}30.4 \% \\
32.6 \% \\
14.1 \% \\
23 \%\end{array}$ \\
\hline $\begin{array}{l}\text { Income } \\
\qquad \begin{aligned} \text { - } & \text { less than US } \$ 1000 \\
\text { - } & \text { US } \$ 1000-2500 \\
- & \text { US } \$ 2501-5000 \\
\text { - } & \text { more than US } \$ 5000\end{aligned}\end{array}$ & $\begin{array}{l}26 \\
61 \\
34 \\
14\end{array}$ & $\begin{array}{l}19.3 \% \\
45.2 \% \\
25.2 \% \\
10.4 \%\end{array}$ \\
\hline
\end{tabular}

